\title{
Spread beyond the border: Small Scale genetic structure of the introduced Banggai cardinalfish (Pterapogon kauderni) population in the Bali Strait
}

\author{
I Nyoman Giri Putra1*, Ni Luh Putu Ria Puspitha ${ }^{1}$, Endang Wulandari Suryaningtyas² \\ ${ }^{1}$ Faculty of Marine Science and Fisheries, Universitas Udayana \\ J. Kampus Bukit Jimbaran, Badung, Bali, 80361 Indonesia \\ 2 Faculty of Agricultural and Environmental Sciences (AUF), Rostock University \\ Justus-von-Liebig-Weg 618059 Rostock, Germany \\ Email: nyomangiriputra@unud.ac.id
}

\begin{abstract}
The living marine aquarium trade has been known to mediate various aquatic invaders to spread and established a new population outside of their natural home range. In most cases, the introduce species cause a cascaded effect which harm the native species and their ecosystem. The successful of the invasion event often related to the genetic properties of the introduced species. Therefore, using a molecular approach based on a mitochondrial DNA marker, the present work aimed to evaluate the population genetic structure of the introduced P. kauderni population in Bali Strait. Samples were collected from four sites in Gilimanuk Bay, Bali Strait. Our results showed a high haplotype diversity and low nucleotide diversity that might be a signal of a bottleneck. Overall, we found five haplotypes comprising two unique haplotypes and three shared haplotypes. Genetic structure was detected in some localities, which indicates Pterapogon kauderni might originated from various genetically distinct populations. However, we could not conclusively determine the observed patterns of the genetic structure within each site. These patterns are likely related to the multiple introduction event of P. kauderni in Bali Strait. Additional samples from both side (introduced and native habitat) combined with more rapidly evolving markers may describe the structure more clearly.
\end{abstract}

Keywords: Aquarium Trade, Banggai Cardinalfish, Bali Strait, Control Region MtDNA, Exotic Species, Invasive

\section{Introduction}

Invasion by alien species (non-indigenous organisms) in marine ecosystems has become a global challenge (Keith et al., 2016; Tsiamis et al., 2020) and the frequency of occurrence may continue to rise substantially over the coming decades (Levine and D'Antonio, 2003). Invasion can occur through shipping activities, the aquarium trade, and mariculture (Maceda-Veiga et al., 2013; Nunes et al., 2014; Venezia et al., 2018). A marine organism that invades a new habitat could disturb ecosystem function by introducing parasites and diseases (Blakeslee et al., 2012; Telfer and Bown, 2012), competition with local species (Silva et al., 2017; Balestri et al., 2018), changing food-web interactions in the ecosystem (Va'zquez-Luis et al., 2013), and can lead to the extinction of local species (Doherty et al., 2016; Gallardo et al., 2016; Ambariyanto, 2017). Cases of non-native marine species introduction have been widely documented in various taxa, including reef fishes (Azour et al., 2015; Bariche et al., 2015; Butterfield et al., 2015), crustacea (Heinonen and Auster, 2012; Koenders et al., 2012; McLay and Fowler, 2013; Lejeusne et al., 2014), molluscs (Ardura et al., 2015; Riquet et al., 2016; Dias et al., 2018) and some marine plants
(Sghaier et al., 2011; Willette and Ambrose, 2012; Ceccherelli and Pinna, 2014).

The Banggai cardinalfish (Pterapogon kauderni) is an endemic species of the Banggai Islands which has been introduced to the Bali Strait (Allen and Erdmann, 2012) and other areas around Sulawesi (Erdmann and Vagelli, 2001; Moore and Ndobe, 2007). In at least one case, $P$. kauderni has become invasive (Erdmann and Vagelli, 2001). The introduction of $P$. kauderni to the Bali Strait probably occurred accidentally through activities related to the ornamental fish aquarium trade (Militz et al., 2016; Rhyne et al., 2017). P. kauderni has been traded by local people in Banggai Islands since 1992 and by 2000 there were around 118,000 fish traded every month (Lunn and Moreau, 2004). While aquaculture should be the main source of the fish production, recent data show that traded fish were reported as wild-caught (Rhyne et al., 2017; Ndobe et al., 2018). The scale of the trade, the limited distribution of the species, and its natural susceptibility to exploitation caused a continued population decline, which makes $P$. kauderni designated as an endangered species according to the World Conservation Union (IUCN RedList) (Allen and Donaldson, 2007). 
The Decree of the Minister of Marine and Fisheries (MMF) No:49/KEPMEN-KP/2018 has been announced to maintain $P$. kauderni populations around the Banggai Islands. This Decree aims to support the conservation and sustainable use of $P$. kauderni in Banggai Islands. Although, this species requires urgent protection due to over-exploitation within its home range, on the other hand, it has been recognized as an introduced fish in Bali, and some locations in Sulawesi (Moore and Ndobe, 2007; Vagelli, 2011). Moreover, the established populations in Lembeh Strait were potentially invasive (Molnar et al., 2008). High densities of $P$. kauderni may harm the benthic communities which are commonly associated with sea urchin and anemones such as other apogonid fishes and anemonefishes (Vagelli, 2011). Therefore, it is important to evaluate the $P$. kauderni populations in their native range and in introduced locations to provide an appropriate management for this species.

P. kauderni larvae show direct development and are presumed to have low dispersal capabilities (Vagelli, 1999). Juveniles of this species are usually found within the parental habitat, settles to particular microhabitats (e.g. seagrasses, sea urchin, anemones, corals, sponges, and mangrove roots), and exhibits low mobility and dispersing capability as adult (Kolm et al., 2005). The limited distribution and connectivity of this species is due to some of the biological aspects such as lack of pelagic dispersal ability, low fecundity, and their attachment to particular substrates in the coral reef (Vagelli, 1999). Recent work on the population structure of $P$. kauderni in the Banggai Islands revealed that populations separated by extremely short distances were genetically distinct (Hoffman et al., 2005). In addition, $P$. kauderni also shows a high level of selfreassignment which mean this species does not tend to spread over long distances (Vagelli et al., 2009).

Meanwhile, the genetic structure of $P$. kauderni that have been introduced to and become established in Bali Strait has not yet been identified. In Bali Strait, the species has been found in Gilimanuk Bay (Lilley, 2008) which is a semienclosed bay with an average depth of 2 meters. According to a previous survey, this species was found in a shallow area and associated with sea urchins, sponges, seagrasses, and corals (Arbi et al., 2019; Putra and Putra, 2019). Referring to several biological factors such as the short duration of pelagic larvae and the tendency for selfreassignment (Allen, 2000), we expected $P$. kauderni in Bali Strait would also show genetic isolation between populations. Therefore, this study aimed to determine the genetic population structure of the introduced $P$. kauderni population in Bali Strait. Understanding genetic structure of an introduced species is important to determine the ecological impact and the potential invasiveness of the species in order to protect local species and surrounded ecosystems.

\section{Materials and Methods}

\section{Sample collections}

Sample collection was conducted at four sites located in Gilimanuk Bay, Bali Strait, Indonesia (Figure 1). From each site, 5-8 P. kauderni specimens were collected using scoop nets while snorkeling in April 2019. A total of 25 specimens were collected and a small tissue sample from each specimen was preserved in $96 \%$ ethanol for subsequent analysis. According to the Decree of the Minister of Marine and Fisheries (MMF) No:49/KEPMEN-KP/2018, the specimen collection in this area could be completed without any special permit.

\section{Molecular analysis}

DNA was extracted from muscle or fin tissues by the Chelex 10\% extraction method (Walsh et al., 1991). The control region of the mitochondrial genome (mtDNA) was amplified with forward primer CRA (TTC CAC CTC TAA CTC CCA AAG CTA G), and reverse primer CRE (CCT GAA GTA GGA ACC AGA TG) (Lee et al., 1995). DNA amplification reaction were made in $25 \mu \mathrm{l}$ reactions with a final concentration of $2 \mathrm{mM} \mathrm{MgCl}_{2}, 0.8 \mathrm{mM}$ of dNTPs, $0.5 \mu \mathrm{M}$ of each primer,1X PCR Buffer, $14.5 \mu \mathrm{dd}_{2} \mathrm{O}, 2.5 \mathrm{U}$ Taq DNA Polymerase, and $1 \mu$ l of DNA template. The PCR was conducted with the following profile: a denaturation step of $94^{\circ} \mathrm{C}$ for $45 \mathrm{sec}$, followed by an annealing temperature of $48^{\circ} \mathrm{C}$ for $45 \mathrm{sec}$ and extension at $72^{\circ} \mathrm{C}$ for $60 \mathrm{sec}$, this cycle was repeated 35 times (Bernardi and Vagelli, 2004). All PCR products were evaluated on $2 \%$ agarose gel. Clear and strong PCR products were sent to $1^{\text {st }}$ Base DNA Sequencing Service.

\section{Data analysis}

All sequences were initially aligned and edited manually using Mega 5 (Tamura et al., 2011). Multiple sequence alignment was done using ClustalW, as implemented in Mega 5 (Tamura et al., 2011). DnaSP ver. 6 (Rozas et al., 2017), was use to calculated the number of segregated sites (S), number of haplotypes $(\mathrm{H})$, haplotype diversity $(\mathrm{Hd})$, and nucleotide diversity ( $\Pi)$. In addition, neutrality tests including Tajima's D and Fu's Fs were estimated for each population using Arlequin Ver 3.5 (Excoffier and Lischer, 2010). To describe the 


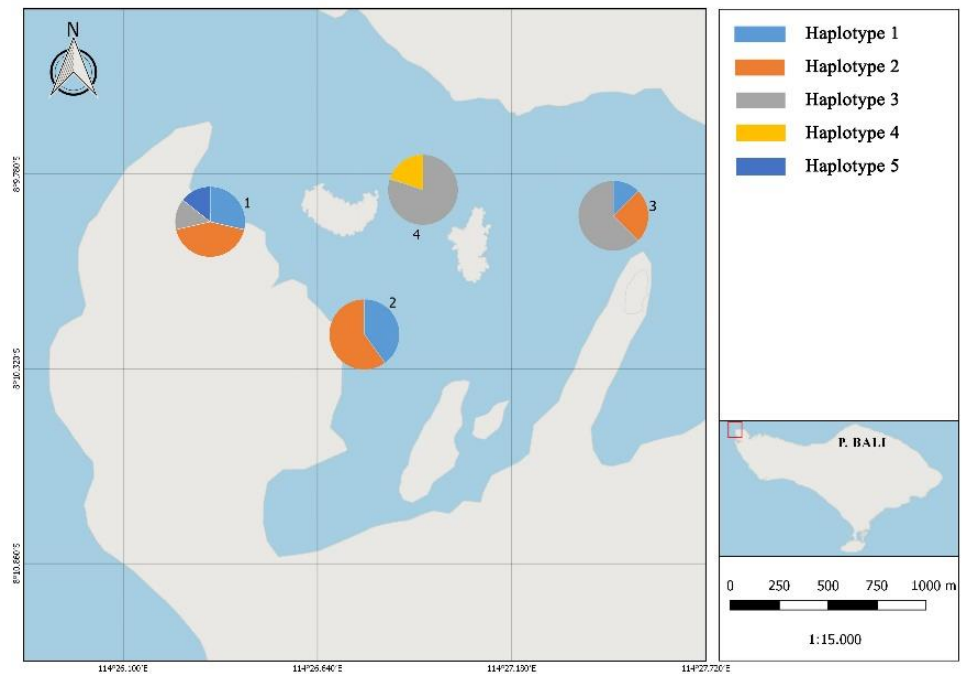

Figure 1. Location of the four P. kauderni sampling sites in Gilimanuk Bay, Bali Island, Indonesia. Pie charts show the mtDNA haplotype distribution of individuals sampled from each site (sites are coded with 1, 2, 3, and 4).

relationship among haplotypes, a Minimum Spanning Network (Bandelt et al., 1999) was use to constructed a haplotype network as implemented in PopART version 1.7 (Leigh and Bryant, 2015). To determine between site population structure, $\Phi_{\mathrm{ST}}$ was estimated between each population pair using the software package Arlequin Ver 3.5 (Excoffier and Lischer, 2010).

\section{Results and Discussion}

\section{Genetic diversity}

Sequences obtained from 25 individuals of $P$. kauderni collected from four sites in Gilimanuk Bay were aligned and analysed (Table 1). Among these 25 individuals, five haplotypes were observed, involving four polymorphic nucleotide sites. Genetic diversity indices showed high levels of haplotype diversity but low nucleotide diversity within the $P$. kauderni population at each sampling site. Haplotype diversity ranged from 0.60 in the population from site 2 to 0.81 in site 1 . Meanwhile, nucleotide diversity ranged from 0.003 to 0.004 (Table 1). The overall number of haplotypes $(\mathrm{H})$ was 5 , haplotype diversity $(\mathrm{Hd})$ was 0.72 , nucleotide diversity, חT was 0.003 . Neutrality tests produced positive values and none of these tests were significant, indicating that the DNA sequence evolving in random process (neutrally) (Table 1).

Endemic species are often characterized by a low abundance (Weir et al., 2011; Baker et al., 2013), making them susceptible to genetic drift which causes decreased in genetic diversity. In contrast, our research found that the introduced $P$. kauderni population in Gilimanuk Bay had high haplotype ( $\mathrm{Hd}>0.5)$ and low nucleotide $(\pi<5 \%)$ diversity. These results suggest that this $P$. kauderni population may have experienced a population bottleneck, which may be associated with the founder effect. Although further analysis using Tajima's D, and Fu's Fs tests could not confirm the results since these tests were not significant. The founder effect occurs when a new population is formed by individuals from a larger population; this can result in changes to allele frequencies relative to the source population, due to the significant reduction in population size (Johnson et al., 2016; Morim et al., 2019). P. kauderni has been spread outside of its native range, mediated by the living marine aquarium trade (Militz et al., 2016; Rhyne et al., 2012). Introduced population sites was found within Sulawesi Island (Vagelli, 2011) and Bali (Allen and Erdmann, 2012). According to trade route data from early 2001, at least 1,000-8,000 P. kauderni were traded by exporters or employer's company in Bali (Lunn and Moreau, 2004). Therefore, this species may possibly have been released in Gilimanuk Bay over several years (Lilley, 2008; Ndobe et al., 2018).

Since the $P$. kauderni population in Gilimanuk Bay is an introduced population, we could expect that this population would have a low level of genetic diversity compared to the population(s) of origin in the Banggai Islands. Contrary to prior expectations, we found that the haplotype diversity of $P$. kauderni in Gilimanuk Bay was similar to that reported for native populations in the Banggai Islands. For instance, the present study found a $\mathrm{Hd}$ range of $0.60-0.81$, while a previous study conducted in the Banggai Islands reported a $\mathrm{Hd}$ range of $0.00-0.82$ (Bernardi and Vagelli, 2004). The increased genetic 
Table 1. Sample collection site, number of samples (n), number of segregated sites (S), number of haplotypes $(H)$, haplotype diversity (Hd), nucleotide diversity (п), Tajima's D (D), and Fu's Fs (Fs) of P. kauderni collected from four sites in Gilimanuk Bay. ns= not significant

\begin{tabular}{|c|c|c|c|c|c|c|c|c|}
\hline Site & Latitude, longitude & $\mathrm{n}$ & $\mathrm{S}$ & $\mathrm{H}$ & $\mathrm{Hd}$ & $\Pi$ & $\mathrm{D}$ & Fs \\
\hline 1 & $-8.16491,114.44025$ & 7 & 3 & 4 & 0.81 & 0.004 & 1.459 ns & $-0.538^{n s}$ \\
\hline 2 & $-8.16951,114.44699$ & 5 & 2 & 2 & 0.60 & 0.003 & $1.459^{\text {ns }}$ & $1.688^{\mathrm{ns}}$ \\
\hline 3 & $-8.16415,114.45550$ & 8 & 3 & 3 & 0.61 & 0.003 & $0.204^{\mathrm{ns}}$ & $0.562^{\text {ns }}$ \\
\hline 4 & $-8.16415,114.45550$ & 5 & 1 & 2 & 0.72 & 0.003 & $-0.816^{n s}$ & $0.090^{n s}$ \\
\hline Total & & 25 & 4 & 5 & 0.72 & 0.003 & $0.95 \mathrm{~ns}$ & $0.105^{n s}$ \\
\hline
\end{tabular}

Table 2. $P$. kauderni population $\Phi_{\mathrm{ST}}$ values (below diagonal) and $\Phi_{\mathrm{ST}} \mathrm{P}$ values (above diagonal) derived using Arlequin ver. 3.5.

\begin{tabular}{lllll}
\hline Site & 1 & 2 & 3 & 4 \\
\hline 1 & 0 & 0.789 & 0.358 & $0.008^{*}$ \\
2 & -0.104 & 0 & 0.124 & $0.008^{*}$ \\
3 & 0.035 & 0.245 & 0 & 0.213 \\
4 & 0.390 & 0.636 & 0.107 & 0 \\
\hline
\end{tabular}

Significant $\Phi_{\mathrm{ST}}$ values marked by bold number with $* P<0.05$.

diversity in aquatic invaders is not surprising as reported in some papers (Lejeusne et al., 2014; Roman, 2006; Guardiola et al., 2016; Arnaud-Haond et al., 2017; Negri et al., 2018). Several mechanisms may work simultaneously to dilute the founder effect (Roman, 2006; Geller et al., 2010). For example, both population growth rates and the probability of establishment could be increase by a large number of released individuals (Lockwood et al., 2005; Johnston and Purkis, 2016). Alternatively, repeated temporal introduction events from genetically distinct source populations could also compensate for the lack of genetic diversity in any one particular introduction event (Lejeusne et al., 2014; Rius et al., 2015). Previous studies have found that $P$. kauderni in the Banggai Islands showed a restricted gene flow and high genetic structuring (Hoffman et al., 2005; Vagelli et al., 2009). Thus, our results suggest that the $P$. kauderni population in Gilimanuk Bay was most likely established through repeated temporally distinct introductions from different areas in the Banggai Islands.

\section{Population structure}

The Minimum Spanning Network is presented in Figure 2. A loop was present in the network, indicating possible alternative relationships among haplotypes. Network analysis showed there were two (40\%) unique haplotypes (Hap_4 and Hap_5) and 3 shared (60\%) haplotypes (Hap_1, Hap_2, and Hap_3) (Figure. 1.). The most common haplotypes were shared by 10 individuals (Hap_3) and this haplotype was found in all sites except site 2 . Haplotype distribution showed there was no shared haplotype between sites 2 and 4 (Figure 2.) These results indicate a low level of gene flow between these two sites, a conjecture further supported by the high $\Phi_{\text {St }}$ values (Table 2). Similarly, sites 1 and 2 also showed a low level of gene flow with just one haplotype shared between these two sites.

According to the $\Phi_{\mathrm{ST}}$ analysis, genetic structure was detected $(P<0.05)$ in some localities (Table 2.). The $\Phi_{\text {St }}$ values range from -0.104 to 0.636 and the highest $\Phi_{\text {ST }}$ values was between site 2 and site 4 (Table 2.). A previous genetic study on $P$. kauderni revealed a low level of gene flow around the Banggai Islands (Hoffman et al., 2005) and on small scale areas in Bangkulu Island (Vagelli et al., 2009). A strong genetic structure was observed in population separated over a distance of $\mathrm{km}$ (Hoffman et al., 2005). Consistent with previous works, our results also found significant genetic structuring within a small-scale area. The limited dispersal potential maybe related to the lack of pelagic larval duration (PLD) (Allen, 2000) and adult philopatric behaviour (Kolm et al., 2005). These are suspected to limit the gene flow in $P$. kauderni such found in some other fish species like blennioid fish (Riginos and Victor, 2001), and anemonefishes (Madduppa et al., 2014; Timm et al., 2017). In fact, coral reef fishes with long-distance dispersal potential can also show strong genetic partitioning (Ravago-Gotanco and Juinio-Meñez, 2010; Ackiss et al., 2013; Pertiwi et al., 2019).

Our data could not definitely determine the genetic structuring within each site based on the observed patterns. Larger sample sizes combine with more rapidly evolving molecular markers might help address this question. Population differentiation was observed between sites 1 and 4 and between sites 2 and 4 (Table 2.), all of which are located quite close to each other. There are no obvious geographical barriers (i.e. strong currents, deep range) between these sites that could promote 


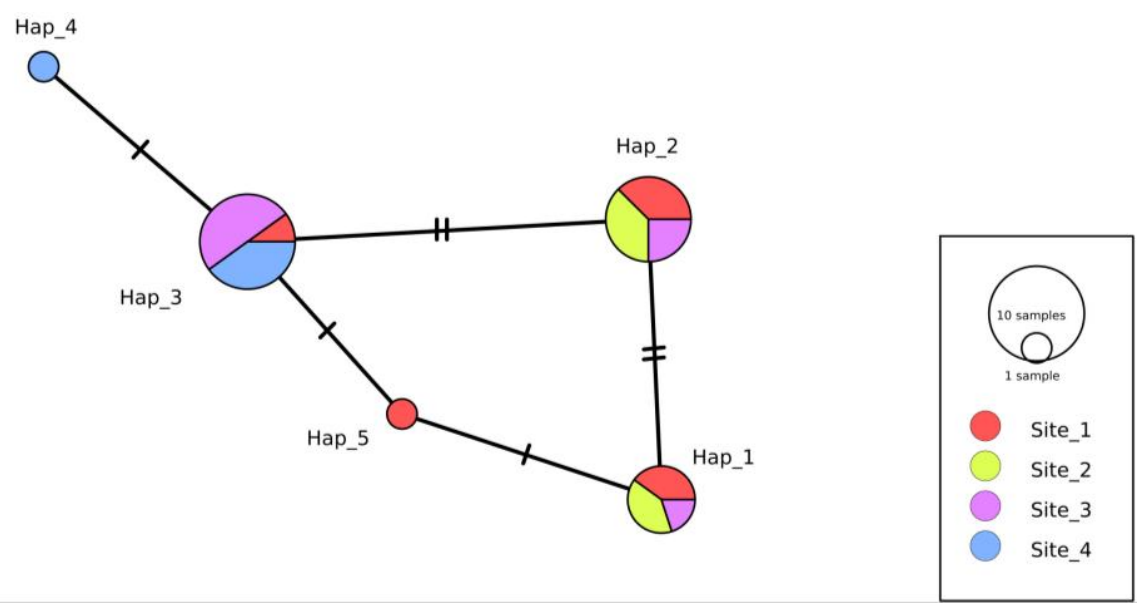

Figure 2. A minimum-spanning network of the control region haplotypes of $P$. kauderni. The size of each circle indicates the haplotype's frequency and each circle represents a unique haplotype. Colours in this case were used to assign haplotypes to four sampling localities (Site_1, 2, 3, 4). Lines on bars that separate haplotypes represent the mutational steps between one haplotype and another.

such differentiation, because Gilimanuk Bay is a semi-enclosed bay with an average depth of 2 meters (Macklin et al., 2019). In the absence of a geographical barrier, we consider that the most reliable explanation for the observed patterns is the origin of the four introduced populations sampled. The fish released at each site probably have come from different populations (sites) in the Banggai Islands. A comprehensive survey conducted in Banggai and nearby islands found that $P$. kauderni was recorded in 34 islands encompassing areas approximately $5000 \mathrm{~km}^{2}$ (Vagelli, 2011). Two previous studies in the Banggai Islands found that each $P$. kauderni population sampled was genetically distinct (Bernardi and Vagelli, 2004; Hoffman et al., 2005). Our data indicate that the introduced population in Gilimanuk Bay seems to have come from several different source populations. Some of the main fish exporters in Bali are known to be based in Gilimanuk Bay and have actively traded $P$. kauderni since 1992 (Lunn and Moreau, 2004). Each company probably has a specific collection site in Banggai Islands, thus affecting the founder population composition and the observed genetic structure. However, further research using larger sample sizes from both the introduced population and potential source locations would be needed to confirm this hypothesis.

In recent years, genetic data have been use broadly for marine biodiversity conservation (Palsbøll et al., 2006; Von Der Heyden et al., 2014; VenegasLi et al., 2016). Genetic approaches have also very useful to determine, trace, and mitigate biological invasion (Hänfling et al., 2011; Bariche et al., 2015; Negri et al., 2018). To the best of our knowledge, this is the first genetic data available for $P$. kauderni in Bali. Thus, we believe that this present work could be useful for management of $P$. kauderni in Bali, particularly for stock delineation. Furthermore, protection of genetic diversity and stock delineation is one of the key priorities for $P$. kauderni conservation and management in Banggai Islands (Moore et al., 2017; Ndobe et al., 2019). Regarding to the introduction of $P$. kauderni in Gilimanuk Bay, recent works have been showed that $P$. kauderni has been found in the entire bay occupying various microhabitat (e.g., sea urchin, seagrasses, hard coral, and sponges) and the populations continue to flourish (Arbi et al., 2019; Putra and Putra, 2019). Therefore, regular monitoring for the $P$. kauderni populations status is important to determine whether they are invasive or not to the surrounding ecosystems.

\section{Conclusion}

Despite the low samples sizes collected during the present study, our results show that the $P$. kauderni population in Gilimanuk Bay, Bali Strait, exhibits high haplotype diversity and low nucleotide diversity. Significant genetic structuring was detected in some localities, indicating low gene flow between some sites. The genetic structure observed within this study might also implied that the founder population of $P$. kauderni in Bali Strait, may have originated from several genetically distinct populations in Banggai Islands. Given the high level of genetic diversity and rapid establishment of $P$. kauderni in Bali Strait, it is important to monitor the populations regularly to prevent this species from harming the native organisms and the rest of ecosystems. 


\section{Acknowledgement}

This study was funded by Universitas Udayana (grant number 442/UN14.2.13/II/LT/2019). The authors thank students of Marine Science, Universitas Udayana for their assistance in field data collection and Yayasan Biodiversitas Indonesia (Bionesia) Bali for supporting the molecular analysis.

\section{References}

Ackiss, A.S., Pardede, S., Crandall, E.D., AblanLagman, M.C.A., Ambariyanto, A., Romena, N., Barber, P.H. \& Carpenter, K.E. 2013. Pronounced genetic structure in a highly mobile coral reef fish, Caesio cuning, in the Coral Triangle. Mar. Ecol. Prog. Ser. 480:185-197. doi: 10.3354/meps10199

Allen, G. \& Erdmann, M. 2012. Reef Fishes of the East Indies. Volume I-III. Tropical Reef Research, Perth, Australia.

Allen, G.R. 2000. Threatened fishes of the world: Pterapogon kauderni Koumans, 1933 (Apogonidae). Environ. Biol. Fishes, 57:142-142. doi: 10.1023/A:1007639909422

Allen, G.R. \& Donaldson, T.J. 2007. Pterapogon kauderni. The IUCN Red List of Threatened Species 2007: e.T63572A12692964., The IUCN Red List of Threatened Species 2007. doi: 10.2305/IUCN.UK.2007.RLTS.T63572A12692 964.en

Ambariyanto, A. 2017. Conserving endangered marine organisms: causes, trends and challenges. IOP Conference Series: Earth and Environmental Science. 55(1):012002. IOP Publishing.

Arbi, U.Y., Suharti, S.R., Huwae, R., Rizqi, M.P. \& Suratno. 2019. Populasi ikan endemik capungan Banggai (Pterapogon kauderni) di habitat introduksi di Teluk Gilimanuk, Bali, in: Istiqomah, I. et al. (Ed.), Seminar Nasional Tahunan XVI Hasil Penelitian Perikanan Dan Kelautan Tahun 2019. Departemen Perikanan Fakultas Pertanian Universitas Gadjah Mada, Yogyakarta, p. 379 pages.

Ardura, A., Planes, S. \& Garcia-vazquez, E. 2015. Aliens in Paradise. Boat density and exotic coastal mollusks in Moorea Island (French Polynesia). Mar. Environ. Res., 112:56-63. doi: 10.1016/j.marenvres.2015.08.007

Arnaud-Haond, S., Aires, T., Candeias, R., Teixeira, S.J.L., Duarte, C.M., Valero, M. \& Serrão, E.A. 2017. Entangled fates of holobiont genomes during invasion: nested bacterial and host diversities in Caulerpa taxifolia. Mol. Ecol., 26:2379-2391. doi: 10.1111/mec.14030

Azour, F., van Deurs, M., Behrens, J., Carl, H., Hüssy, K., Greisen, K., Ebert, R. \& Møller, P. 2015. Invasion rate and population characteristics of the round goby Neogobius melanostomus: effects of density and invasion history. Aquat. Biol., 24:41-52. doi: 10.3354/ab00634

Baker, C.S., Hamner, R.M., Cooke, J., Heimeier, D., Vant, M., Steel, D. \& Constantine, R. 2013. Low abundance and probable decline of the critically endangered Maui's dolphin estimated by genotype capture-recapture. Anim. Conserv., 16:224-233. doi: 10.1111/j.1469-1795.20 12.00590.x

Balestri, E., Vallerini, F., Menicagli, V., Barnaba, S. \& Lardicci, C. 2018. Biotic resistance and vegetative propagule pressure co-regulate the invasion success of a marine clonal macrophyte. Sci. Rep., 8:1-11. doi: 10.1038/ s41598-018-35015-0

Bandelt, H., Forster, P. \& Arne, R. 1999. MedianJoining Networks for Inferring Intraspecific Phylogenies. Mol. Biol. Evol. 16:37-48.

Bariche, M., Torres, M., Smith, C., Sayar, N., Azzurro, E., Baker, R. \& Bernardi, G. 2015. Red Sea fishes in the Mediterranean Sea : a preliminary investigation of a biological invasion using DNA barcoding. J. Biogeogr., 42:2363-2373. doi: 10.1111/jbi.12595

Bernardi, G. \& Vagelli, A., 2004. Population structure in Banggai cardinalfish, Pterapogon kauderni, a coral reef species lacking a pelagic larval phase. Mar. Biol., 145:803-810. doi: 10.10 07/s00227-004-1355-1

Blakeslee, A.M.H., Altman, I., Miller, A.W., Byers, J.E., Hamer, C.E., \& Ruiz, G.M., 2012. Parasites and invasions: a biogeographic examination of parasites and hosts in native and introduced ranges. J. Biogeogr., 39:609-622. doi: 10.11 11/j.1365-2699.2011.02631.x

Butterfield, J.S.S., Díaz-Ferguson, E., Silliman, B.R., Saunders, J.W., Buddo, D., Mignucci-Giannoni, A. a., Searle, L., Allen, A.C. \& Hunter, M.E. 2015. Wide-ranging phylogeographic structure of invasive red lionfish in the Western Atlantic and Greater Caribbean. Mar. Biol., 162:773-781. doi: 10.1007/s00227-015-2623-y

Ceccherelli, G. \& Pinna, S., 2014. The role of disturbance in promoting the spread of the invasive seaweed Caulerpa racemosa in seagrass meadows. Biol. Invasions, 16:27372745. doi: 10.1007/s10530-014-0700-7 
Dias, P.J., Gilg, M.R., Lukehurst, S.S., Kennington, W.J., Huhn, M., Madduppa, H.H., McKirdy, S.J., de Lestang, P., Teo, S.L.M., Lee, S.S.C. \& McDonald, J.I., 2018. Genetic diversity of a hitchhiker and prized food source in the Anthropocene: the Asian green mussel Perna viridis (Mollusca, Mytilidae). Biol. Invasions, 20:1749-1770. doi: 10.1007/s10530-018-16 59-6

Doherty, T.S., Glen, A.S., Nimmo, D.G., Ritchie, E.G. \& Dickman, C.R. 2016. Invasive predators and global biodiversity loss. Proc. Natl. Acad. Sci. USA., 113:11261-11265. doi: 10.1073/pnas. 1602480113

Erdmann, M.V. \& Vagelli, A., 2001. Banggai cardinalfish invade Lembeh Strait. Coral Reefs, 20:252-253. doi: 10.1007/s003380100174

Excoffier, L. \& Lischer, H.E.L. 2010. Arlequin suite ver 3.5: A new series of programs to perform population genetics analyses under Linux and Windows. Mol. Ecol. Resour. 10:564-567. doi: 10.1111/j.1755-0998.2010.02847.x

Gallardo, B., Clavero, M., Sánchez, M.I. \& Vilà, M. 2016. Global ecological impacts of invasive species in aquatic ecosystems. Glob. Chang. Biol. 22:151-163. doi: 10.1111/gcb.13004

Geller, J.B., Darling, J.A., \& Carlton, J.T. 2010. Genetic Perspectives on Marine Biological Invasions. Ann. Rev. Mar. Sci., 2:367-393. doi: 10.1146/annurev.marine.010908.163745

Guardiola, M., Frotscher, J. \& Uriz, M.J. 2016. High genetic diversity, phenotypic plasticity, and invasive potential of a recently introduced calcareous sponge, fast spreading across the Atlanto-Mediterranean basin. Mar. Biol., 163:116. doi: 10.1007/s00227-016-2862-6

Hänfling, B., Edwards, F. \& Gherardi, F. 2011. Invasive alien Crustacea: Dispersal, establishment, impact and control. BioControl, 56:573-595. doi: 10.1007/s10526-011-9380-8

Heinonen, K.B. \& Auster, P.J. 2012. Prey selection in crustacean-eating fishes following the invasion of the Asian shore crab Hemigrapsus sanguineus in a marine temperate community. J. Exp. Mar. Bio. Ecol. 413: 77-183. doi: 10.1016/j.jembe.2011.12.011

Hoffman, E.A., Kolm, N., Berglund, A., Arguello, J.R. \& Jones, A.G. 2005. Genetic structure in the coral-reef-associated Banggai cardinalfish, Pterapogon kauderni. Mol. Ecol. 14: 1367-1375. doi: 10.1111/j.1365-294X.2005.02 53 8.x
Johnson, J., Bird, C.E., Johnston, M.A., Fogg, A.Q. \& Derek Hogan, J. 2016. Regional genetic structure and genetic founder effects in the invasive lionfish: comparing the Gulf of Mexico, Caribbean and North Atlantic. Mar. Biol., 163: 216. doi: 10.1007/s00227-016-2981-0

Johnston, M.W. \& Purkis, S.J. 2016. Forecasting the success of invasive marine species; lessons learned from purposeful reef fish releases in the Hawaiian Islands. Fish. Res. 174: 190200. doi: 10.1016/j.fishres.2015.10.011

Keith, I., Dawson, T.P., Collins, K.J. \& Campbell, M.L. 2016. Marine invasive species: establishing pathways, their presence and potential threats in the Galapagos Marine Reserve. Pacific Conserv. Biol., 22: 377-385. doi: 10.1071/PC 15020

Koenders, A., Martens, K., Halse, S. \& Scho, I. 2012. Cryptic species of the Eucypris virens species complex (Ostracoda, Crustacea) from Europe have invaded Western Australia. Biol Invasions 14: 2187-2201. doi: 10.1007/s10530-012 02 24-y

Kolm, N., Hoffman, E.A., Olsson, J., Berglund, A. \& Jones, A.G. 2005. Group stability and homing behavior but no kin group structures in a coral reef fish. Behav. Ecol. 16: 521-527. doi: 10.1093/beheco/ari022

Lee, W., Conroy, J., Howell, W. \& Kocher, T. 1995. Structure and evolution of teleost mitochondrial control regions. J. Mol. Evol., 41: 54-66.

Leigh, J.W. \& Bryant, D. 2015. Popart: full-feature software for haplotype network construction. Methods Ecol. Evol. 6: 1110-1116. doi: 10.11 11/2041-210X.12410

Lejeusne, C., Saunier, A., Petit, N., Béguer, M., Otani, M., Carlton, J.T., Rico, C. \& Green, A.J. 2014. High genetic diversity and absence of founder effects in a worldwide aquatic invader. Sci. Rep. 4: 1-9 doi: $10.1038 /$ srep05808

Levine, J.M., \& D'Antonio, C.M., 2003. Forecasting Biological Invasions with Increasing International Trade. Conserv. Biol., 17: 322-326.

Lilley, R., 2008. The Banggai cardinalfish: An overview of conservation challenges. SPC Live Reef Fish Inf. Bull. 12pp.

Lockwood, J.L., Cassey, P. \& Blackburn, T. 2005. The role of propagule pressure in explaining species invasions. Trends Ecol. Evol. 20: 223-228. doi: 10.1016/j.tree.2005.02.004

Lunn, K.E. \& Moreau, M.A., 2004. Unmonitored trade in marine ornamental fishes: the case of Indonesia's Banggai cardinalfish (Pterapogon 
kauderni). Coral Reefs, 23: 344-351. doi: 10.1007/s00338-004-0393-y

Maceda-Veiga, A., Escribano-Alacid, J., Sostoa, A. de. \& Garrcia-Berthou, E. 2013. The aquarium trade as a potential source of fish introductions in southwestern Europe. Biol. Invasions, 15:2707-2716. doi: 10.1007/s10530-013-0 485-0

Macklin, P.A., Suryaputra, I.G.N.A., Maher, D.T., Murdiyarso, D. \& Santos, I.R. 2019. Drivers of $\mathrm{CO}_{2}$ along a mangrove-seagrass transect in a tropical bay: Delayed groundwater seepage and seagrass uptake. Cont. Shelf Res., 172: 57-67. doi: 10.1016/j.csr.2018.10.008

Madduppa, H.H., Timm, J., \& Kochzius, M., 2014. Interspecific, spatial and temporal variability of self-recruitment in anemonefishes. PLOS One, 9:e90648. doi: 10.1371/journal.pone.0090648

McLay, C.L., \& Fowler, A.E., 2013. Early stages of a New Zealand invasion by Charybdis japonica (A. Milne-Edwards, 1861) (Brachyura: Portunidae) from Asia: population demography. J. Crustac. Biol., 33: 224-234. doi: 10.1163/1937240X00002127

Militz, T.A., Kinch, J., Foale, S., \& Southgate, P.C., 2016. Fish rejections in the marine aquarium trade: An initial case study raises concern for village-based fisheries. PLoS One, 11: e0151624. doi: 10.1371/journal.pone. 0151624

Molnar, J.L., Gamboa, R.L., Revenga, C., \& Spalding, M.D., 2008. Assessing the global threat of invasive species to marine biodiversity. Front. Ecol. Environ. 6: 485-492. doi: 10.1890/070 064

Moore, A., \& Ndobe, S., 2007. Discovery of an introduced Banggai Cardinalfish population in Palu Bay, Central Sulawesi, Indonesia. Coral Reefs 26: 569-569. doi: 10.1007/s00338-0 07-0227-9

Moore, A.M., Ndobe, S., \& Jompa, J., 2017. A site based conservation approach to promote the recovery of Banggai cardinalfish (Pterapogon kauderni) endemic populations. Coast. Ocean J., 1: 63-72.

Morim, T., Bigg, G.R., Madeira, P.M., Palma, J., Duvernell, D.D., Gisbert, E., Cunha, R.L. \& Castilho, R. 2019. Invasion genetics of the mummichog (Fundulus heteroclitus): recent anthropogenic introduction in Iberia. PeerJ, 7: e6155. doi: 10.7717/peerj.6155
Ndobe, S., Moore, A.M., Yasir, I. \& Jompa, J. 2019. Banggai cardinalfish conservation: Priorities, opportunities, and risks. IOP Conf. Ser. Earth Environ. Sci. 253: 1-14. doi: 10.1088/17551315/253/1/012033

Ndobe, S., Yasir, I., Moore, A.M., Biondo, M.V. \& Foster, S.J. 2018. A study to assess the impact of international trade on the conservation status of Pterapogon kauderni (Banggai cardinalfish). Convention on International Trade in Endangered Species of Wild Fauna and Flora: Thirtieth meeting of the Animals Committee Geneva (Switzerland), 16-21 July 2018.

Negri, M., Schubart, C.D. \& Mantelatto, F.L. 2018. Tracing the introduction history of the invasive swimming crab Charybdis hellerii (A. MilneEdwards, 1867) in the Western Atlantic: evidences of high genetic diversity and multiple introductions. Biol. Invasions, 20: 1771-1798. doi: 10.1007/s10530-018-1660-0

Nunes, A.L., Katsanevakis, S., Zenetos, A. \& Cardoso, A.C. 2014. Gateways to alien invasions in the European seas. Aquat. Invasions, 9: 133-144. doi: 10.3391/ai.2014. 9.2.02

Palsbøll, P.J., Berube, M. \& Allendorf, F.W. 2006. Identification of management units using population genetic data. Trends Ecol. Evol., 22:11-16. doi: 10.1016/j.tree.2006.09.003

Pertiwi, N.P.D., Hidayat, N.I., Henderson, C., Putra, I.N.G. \& Sembiring, A. 2019. Redefining Dispersal Boundaries of Siganus fuscescens In The Coral Triangle Area. IImu Kelautan: Indonesia Journal Marine Science, 24(1): 3140. doi : 10.14710/ik.jjms.24.1.31-40

Putra, I.N.G. \& Putra, I.D.N.N. 2019. Recent Invasion of the Endemic Banggai Cardinalfish, Pterapogon kauderni at The Strait of Bali: Assessment of the Habitat Type and Population Structure. IImu Kelautan: Indonesia Journal Marine Science, 24(1): 15-22. doi: 10.14 710/ik.ijms.24.1.15-22

Ravago-Gotanco, R.G. \& Juinio-Meñez, M. 2010. Phylogeography of the mottled spinefoot Siganus fuscescens: Pleistocene divergence and limited genetic connectivity across the Philippine archipelago. Mol. Ecol., 19: 45204534. doi: 10.1111/j.1365-294X.2010.04803.x

Rhyne, A.L., Tlusty, M.F., Schofield, P.J., Kaufman, L., Morris, J.A., \& Bruckner, A.W., 2012. Revealing the Appetite of the Marine Aquarium Fish Trade: The Volume and Biodiversity of Fish Imported into the United States. PLoS One, 7: e35808. doi: 10.1371/journal.pone.0035808 
Rhyne, A.L., Tlusty, M.F., Szczebak, J.T., \& Holmberg, R.J., 2017. Expanding our understanding of the trade in marine aquarium animals. PeerJ, 5: e2949. doi: 10.7717/peerj.2949

Riginos, C., \& Victor, B.C., 2001. Larval spatial distributions and other early life-history characteristics predict genetic differentiation in eastern Pacific blennioid fishes. Proc. R. Soc. B Biol. Sci., 268: 1931-1936. doi: 10.1098/rs pb.2001.1748

Riquet, F., Le Cam, S., Fonteneau, E., \& Viard, F., 2016. Moderate genetic drift is driven by extreme recruitment events in the invasive mollusk Crepidula fornicata. Heredity (Edinb). 117: 42-50. doi: 10.1038/hdy.2016.24

Rius, M., Turon, X., Bernardi, G., Volckaert, F.A.M. \& Viard, F. 2015. Marine invasion genetics: from spatio-temporal patterns to evolutionary outcomes. Biol. Invasions, 17: 869-885. doi: 10.1007/s10530-014-0792-0

Roman, J., 2006. Diluting the founder effect: cryptic invasions expand a marine invader's range. Proc. R. Soc. B Biol. Sci., 273: 2453-2459. doi: 10.1098/rspb.2006.3597

Rozas, J., Ferrer-mata, A., Sanchez-Delbarrio, J.C., Guirao-rico, S., Librado, P., Ramos-onsins, S., \& Sanchez-Gracia, S., 2017. DnaSP 6: DNA Sequence Polymorphism Analysis of Large Data Sets. Mol. Biol. Evol., 34: 3299-3302. doi: 10.1093/molbev/msx248

Sghaier, Y.R., Zakhama-sraieb, R., Benamer, I. \& Charfi-Cheikhrouha, F. 2011. Occurrence of the seagrass Halophila stipulacea (Hydrocharitaceae) in the southern Mediterranean Sea. Bot. Mar., 54: 575-582. doi: 10.1515/BOT.2011.0 61

Silva, A.G., Fortunato, H.F.M., Lôbo-Hajdu, G., \& Fleury, B.G., 2017. Response of native marine sponges to invasive Tubastraea corals: a case study. Mar. Biol., 164: 1-11. doi: 10.1007/s00 227-017-3112-2

Tamura, K., Peterson, D., Peterson, N., Stecher, G., Nei, M., \& Kumar, S., 2011. MEGA5: Molecular evolutionary genetics analysis using maximum likelihood, evolutionary distance, and maximum parsimony methods. Mol. Biol. Evol., 28: 27312739. doi: 10.1093/molbev/msr121

Telfer, S., \& Bown, K., 2012. The effects of invasion on parasite dynamics and communities. Funct. Ecol., 26: 1288-1299. doi: 10.1111/j.13652435.2012.02049.x
Timm, J., Kochzius, M., Madduppa, H.H., Neuhaus, A.I., \& Dohna, T., 2017. Small Scale Genetic Population Structure of Coral Reef Organisms in Spermonde Archipelago, Indonesia. Front. Mar. Sci., 4: 294 doi: 10.3389/fmars.2017.00294

Tsiamis, K., Azzurro, E., Bariche, M., Çinar, M.E., Crocetta, F., De Clerck, O., Galil, B., Gómez, F., Hoffman, R., Jensen, K.R., Kamburska, L., Langeneck, J., Langer, M.R., Levitt-Barmats, Y., Lezzi, M., Marchini, A., Occhipinti-Ambrogi, A., Ojaveer, H., Piraino, S., Shenkar, N., Yankova, M., Zenetos, A., Žuljević, A. \& Cardoso, A.C. 2020. Prioritizing marine invasive alien species in the European Union through horizon scanning. Aquat. Conserv. Mar. Freshw. Ecosyst., 30: 794-845. doi: 10.1002/aqc.32 67

Va'zquez-Luis, M., Sanchez-jerez, P. \& BayleSempere, J.T. 2013. Does the invasion of Caulerpa racemosa var. cylindracea affect the feeding habits of amphipods (Crustacea: Amphipoda)? J. Mar. Biol. Assoc. U.K., 93: 8794. doi: $10.1017 /$ S002531 5412000288

Vagelli, A., 1999. The Reproductive Biology and Early Ontogeny of the Mouthbrooding Banggai Cardinalfish, Pterapogon Kauderni (Perciformes, Apogonidae). Environ. Biol. Fishes. 56: 79-92. doi: 10.1023/A:10075146 25811

Vagelli, A., Burford, M. \& Bernardi, G. 2009. Fine scale dispersal in Banggai Cardinalfish, Pterapogon kauderni, a coral reef species lacking a pelagic larval phase. Mar. Genomics 1: 129-134. doi: 10.1016/j.margen.2009.01. 001

Vagelli, A.A. 2011. The Banggai Cardinalfish: Natural History, Conservation, and Culture of Pterapogon kauderni. Wiley-Blackwell, UK. 203pp. doi: 10.1002/9781119950387.

Venegas-Li, R., Cros, A., White, A. \& Mora, C. 2016. Measuring conservation success with missing Marine Protected Area boundaries: A case study in the Coral Triangle. Ecol. Indic., 60: 119 -124. doi: 10.1016/j.ecolind.2015.06.02 7

Venezia, L. Della, Samson, J. \& Leung, B. 2018. The rich get richer: Invasion risk across North America from the aquarium pathway under climate change. Biodivers. Res. 24: 285-296. doi: $10.1111 /$ ddi.12681

Von Der Heyden, S., Beger, M., Toonen, R.J., Van Herwerden, L., Juinio-Meñez, M.A., RavagoGotanco, R., Fauvelot, C. \& Bernardi, G. 2014. The application of genetics to marine management and conservation: Examples from 
ILMU KELAUTAN: Indonesian Journal of Marine Sciences September 2021 Vol 26(3):163-172

the Indo-Pacific. Bull. Mar. Sci., 90: 123-158. doi: 10.5343/bms.2012.1079

Walsh, P., Metzger, D. \& Higuchi, R. 1991. Chelex 100 as a medium for simple extraction of DNA for PCR-based typing from forensic material. Biotechniques, 10: 506-513.

Weir, C.R., Van Waerebeek, K., Jefferson, T.A. \& Collins, T. 2011. West Africa's Atlantic humpback dolphin (Sousa teuszii): endemic, enigmatic and soon Endangered? African Zool., 46: 1-17. doi: 10.1080/15627020.2011.114 07473

Willette, D.A. \& Ambrose, R.F. 2012. Effects of the invasive seagrass Halophila stipulacea on the native seagrass, Syringodium filiforme, and associated fish and epibiota communities in the Eastern Caribbean. Aquat. Bot. 103: 7482. doi: 10.1016/j.aquabot.2012.06.007 